\title{
Measurements of the Corrosion of Low-Carbon Steel Drums Under Environmental Conditions at Hanford: One-Year Test Results
}

Prepared for the U.S. Department of Energy Office of Environmental Restoration and Waste Management

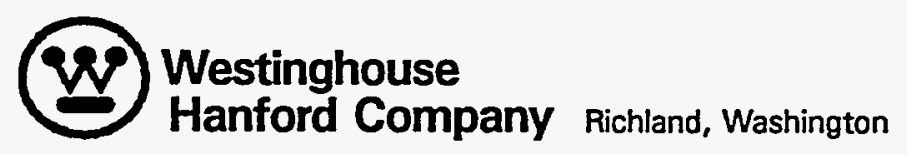

Hanford Operations and Engineering Contractor for the

U.S. Department of Energy under Contract DE-AC06-87RL10930 


\section{Measurements of the Corrosion of Low-Carbon Steel Drums Under Environmental Conditions at Hanford: One-Year Test Results}

D. R. Duncan

Westinghouse Hanford Company

L. R. Bunnell

Pacific Northwest Laboratory

Date Published

May 1995

Prepared for the U.S. Department of Energy Office of Environmental Restoration and Waste Management

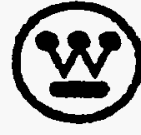




\section{DISCLAIMER}

This report was prepared as an account of work sponsored by an agency of the United States Government. Neither the United States Government nor any agency thereof, nor any of their employees, make any warranty, express or implied, or assumes any legal liability or responsibility for the accuracy, completeness, or usefulness of any information, apparatus, product, or process disclosed, or represents that its use would not infringe privately owned rights. Reference herein to any specific commercial product, process, or service by trade name, trademark, manufacturer, or otherwise does not necessarily constitute or imply its endorsement, recommendation, or favoring by the United States Government or any agency thereof. The views and opinions of authors expressed herein do not necessarily state or reflect those of the United States Government or any agency thereof. 


\section{DISCLAIMER}

Portions of this document may be illegible in electronic image products. Images are produced from the best available original document. 


\section{RELEASE AUTHORIZATION}

\section{Document Number: WHC-EP-0859}

$\begin{array}{ll} & \text { INTERIM REPORT ON THE MEASUREMENT OF THE CORROSI } \\ \text { Document Title: } & \text { OF LOH-CARBON STEEL DRUMS UNDER ENVIRONMENTAL } \\ & \text { CONDITIONS AT THE HANFORD SITE: ONE YEAR TEST } \\ & \text { RESULTS }\end{array}$

Release Date: $\quad 5 / 17 / 95$

This document was reviewed following the procedures described in WHC-CM-3-4 and is:

\section{APPROVED FOR PUBLIC RELEASE}

WHC Information Release Administration Specialist:

(his) Hrilleigham

c. Willingham

$5 / 17 / 95$ 
WHC-EP-0859

\section{CONTENTS}

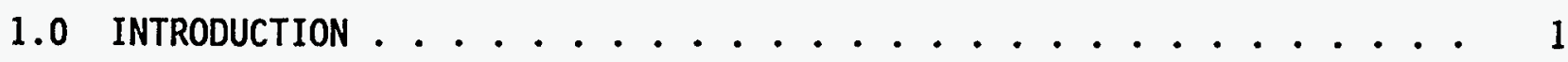

2.0 ATMOSPHERIC CORROSION .................... 3

2.1 EXPERIMENTAL . . . . . . . . . . . 3

2.2 RESULTS AND DISCUSSION $\ldots \ldots \ldots \ldots$

2.3 CONCLUSIONS $\ldots \ldots \ldots 5$

3.0 SOIL CORROSION ..................... 8

3.1 EXPERIMENTAL . . . . . . . . . . . . . 8

3.2 RESULTS AND DISCUSSION . . . . . . . . . . . 8

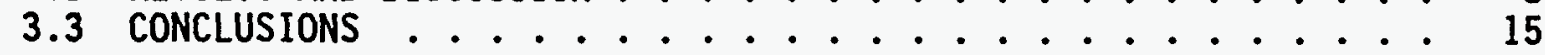

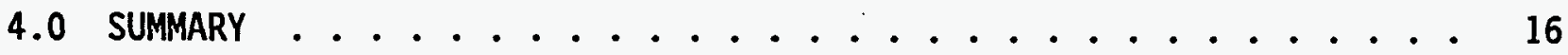

5.0 REFERENCES ........................... 17

\section{FIGURES}

1. Paint-damaged Steel Specimen from Rag-filled Drum with Corrosion Sites Marked ................. 5

2. Paint-damaged Steel Specimen from Sand-filled Drum with Corrosion Sites Marked ................. 5

3. Temperature Measurements from Side of Rag-filled Drum for First 15 Months of Atmospheric Corrosion Test ......... 6

4. Humidity and Wetness Measurements for First 15 Months of Atmospheric Corrosion Test . . . . . . . . . . 7

5a. Metal Specimens Attached to Polyethylene Block . . . . . . . . 10

5b. Specimen Mounting Block in PVC Pipe, Ready for Burial . . . . . 10

6. Shaft Layout at Soil Corrosion Site Showing Specimen and Instrument Locations .................. 11

7. Corrosion Rates Indicated by Low-carbon Steel Resistance Probes Buried at the Indicated Depths .............. 14

8. Soil Moisture Measurements at Soil Corrosion Site in Spring $1994 \ldots \ldots \ldots . . \ldots . . . \ldots$ 
WHC-EP-0859

\section{TABLES}

1. General Corrosion Calculated from Weight-Loss Measurements . . . . 11

2. General Corrosion Calculated from Weight-Loss Measurements . . . . 11 


\section{An Interim Report on the Measurement of the Corrosion of Low-Carbon Steel Drums Under Environmental Conditions at Hanford: One-Year Test Results}

\subsection{INTRODUCTION}

At the Hanford Site, located in southeastern Washington state, nuclear production reactors were operated from 1944 to 1970 . The reactors produced plutonium for the United States nuclear arsenal. The handling and processing of radioactive nuclear fuels produced a large volume of low-level nuclear wastes, chemical wastes, and a combination of the two (mixed wastes). These materials have historically been packaged in U.S. Department of Transportation (DOT) drums made from low-carbon steel, then handled in one of three ways:

A. Before 1970, the drums were buried in the dry desert soil. It was assumed that chemical and radionuclide mobility would be low and that the isolated, government-owned site would provide sufficient protection for employees and the public.

B. After 1970, the drums containing long-lived transuranic radionuclides were protected from premature failure by stacking them in an ordered array on an asphalt concrete pad in the bottom of a burial trench. The array was then covered with a large, $0.28-\mathrm{mm}-(011-i n .-)$ thick polyethylene tarp and the trench was backfilled with $1.3 \mathrm{~m}(4 \mathrm{ft})$ of soil cover. This burial method is referred to as soil-shielded burial. Other configurations were al so employed but the soil-shielded burial method contains most of the transuranic drums.

C. Since 1987, U.S. Department of Energy sites have complied with the Resource Conservation and Recovery Act of 1976 (RCRA) regulations. These regulations require mixed waste drums to be stored in RCRAcompliant large metal sheds with provisions for monitoring. These sheds are provided with forced ventilation but are not heated or cooled.

The drums presently used meet the specifications for DOT Type 17H or 17C drums. The most recent drums meet the new DOT performance-based packaging standards. The 208-L (55-gal) drums are 1iquid-tight through use of gaskets and sealants and are painted with a chemically resistant epoxy on the outer surfaces. A bolted ring securely attaches the lids of these drums.

To determine (1) how long waste materials might reasonably be contained and (2) how much corrosion might be present during planned retrieval efforts for certain waste classes, the corrosion rate of low-carbon steel in the three environments outlined above must be determined. Experimental work has been done to provide information on the corrosion of both nondamaged and damaged drums. In addition, possible alternative materials (e.g., galvanized steel or common stainless steel) have been tested. 
This report describes the methods used to expose low-carbon stee] specimens to atmospheric and soil corrosion and describes methods used to examine specimens retrieved from both types of tests. The first-year testing results for atmospheric corrosion are discussed in Section 2.0; the first year results for soil corrosion are in Section 3.0. 


\subsection{ATMOSPHERIC CORROSION}

\subsection{EXPERIMENTAL}

In the atmospheric corrosion test, specimens taken from newly procured DOT waste drums were directly attached to two steel drums. One of the drums was filled with sand to produce a high thermal mass and one was filled with rags to produce a low thermal mass. The corrosion specimens were attached to the drums on the top, side, and bottom using nylon screws, to prevent possible galvanic effects, and tapered nylon washers were used between specimens and fasteners to avoid formation of a moisture-trapping crevice. Several types of specimens, measuring $2.5-\mathrm{cm}(2-i n$.$) square, were used:$

- Bare low-carbon steel, stripped of epoxy paint covering (18 per drum)

- Painted, as-received, undamaged (9 per drum)

- Painted, damaged by scratches through the paint using a tungsten carbide scribe, on a $1.5-\mathrm{cm}\left(1 / 2-\mathrm{in}_{.}\right)$grid (9 per drum)

- Galvanized, as-received ( 9 per drum)

- Galvanized, with zinc removed from the central area of the specimen by grinding through the zinc to the base metal ( 9 per drum).

The experimental apparatus included sensors for measuring temperature and humidity and for determining whether a water film is present. These data were logged using a portable data logger (the information is available for correlations with corrosion observations). The atmospheric corrosion test was initiated in June 1993. Specimens were retrieved after total exposure times of 182 or 427 days in the 2401-W Building. After retrieval, specimens were stored in a desiccator until they could be examined. Painted and galvanized specimens were examined visually using a stereomicroscope at magnifications up to 70 times. Bare specimens were weighed before the test began and were weighed again after removal of the corrosion products in a bath of CP-9 (hydrochloric acid inhibited with formaldehyde), which is designed to dissolve corrosion products but not the underlying unaffected metal. The weight loss was used to calculate the average corrosion.

\subsection{RESULTS AND DISCUSSION}

Bare steel specimens exposed for either 6 or 12 months showed very small (1.6- to 3.2-mm- [1/16- to 1/8-in.-] -diameter) spots that appeared to be hematite, $\mathrm{Fe}_{2} \mathrm{O}_{3}$ or goethite, $\mathrm{HFeO}_{2}$ by their color. These corrosion products covered less than $50 \%$ of the exposed surface. After these corrosion products were removed weighing indicated that the average metal lost to corrosion was very small (i.e., $0.04 \mu[1.5 \mathrm{E}-3 \mathrm{mil}]$ ). This metal loss is negligible in itself, indicating only that the corrosion process had just begun on these 
specimens. Specimens exposed for approximately 1 year showed slightly more weight loss from corrosion, with a calculated corrosion rate of $0.3 \mu / \mathrm{yr}$ $(1 \mathrm{E}-2 \mathrm{mil} / \mathrm{yr})$.

Electrical resistance corrosion probes made of low-carbon steel (similar to that used for DOT drums) had been attached to the top of each drum. The resistance elements were very thin, $50 \mu$ (0.002 in.), to provide high sensitivity to the low corrosion rate expected in this environment. These probes are monitored monthly and have exhibited the same type of spotty corrosion coverage seen on the bare steel specimens. Monthly electrical resistance measurements show small positive and negative changes from the original value; however, no changes large enough to calculate a corrosion rate. Since these probes measure the average metal thickness remaining, they are not expected to indicate the very small amount of corrosion noted above. An average loss of $0.2 \mu$ ( $1 \mathrm{E}-5$ in.) should be detectable by the resistance probes, and the most recent electrical resistance measurements indicate a change of about that magnitude. Future measurements will calculate a corrosion rate for the steel exposed to atmospheric conditions in storage.

When painted, nondamaged specimens were examined after exposure. There was no evidence of corrosion on specimens attached to either the rag-filled or the sand-filled drums. Painted, damaged specimens were examined, and the only corrosion noted was tiny hematite or goethite deposits on the steel in the bottom of the scratches. The paint had not lifted visibly, indicating that the corrosion sites had not yet spread laterally at the paint-steel interface. The corrosion sites were marked to make them obvious in photographs (see Figures 1 and 2). There was a difference in the number of corrosion sites on the two specimens. The specimen attached to the side of the rag-filled drum had 153 corrosion sites, while the one attached to the side of the sand-filled drum had only 70 sites. The rag-filled drum would be expected to follow ambient temperature more closely than the sand-filled drum because of its smaller thermal mass. However, the difference in response observed may be simply due to random variations in surface metal condition. Galvanized specimens, whether damaged or not, showed no observable damage on either drum.

The test setup instrumentation provides a good characterization of the environmental conditions affecting the corrosion specimens. Figure 3 shows the temperatures over the first 15 months of testing as measured on the side of the rag-filled drum. Gaps in the data occurred primarily because of difficulties with the data logger storage battery. The seasonal variations are in line with expectations for a building provided with air flow but no heating or cooling. Figure 4 shows humidity and wetness for the first 15 months of the test, and it is apparent that the humidity approached $100 \%$ during the winter of 1993-1994. Though the relative humidity was high, the air apparently did not contain enough water to form a continuous film. As shown in Figure 4 , the wetness sensor never indicated a water film. The presence of a water film would have increased the output of the wetness sensor by a magnitude of approximately 100 . The absence of water films on the specimens is believed to be responsible for the minimal corrosion observed during the first year of exposure. While a stable oxide forms on steel exposed to 


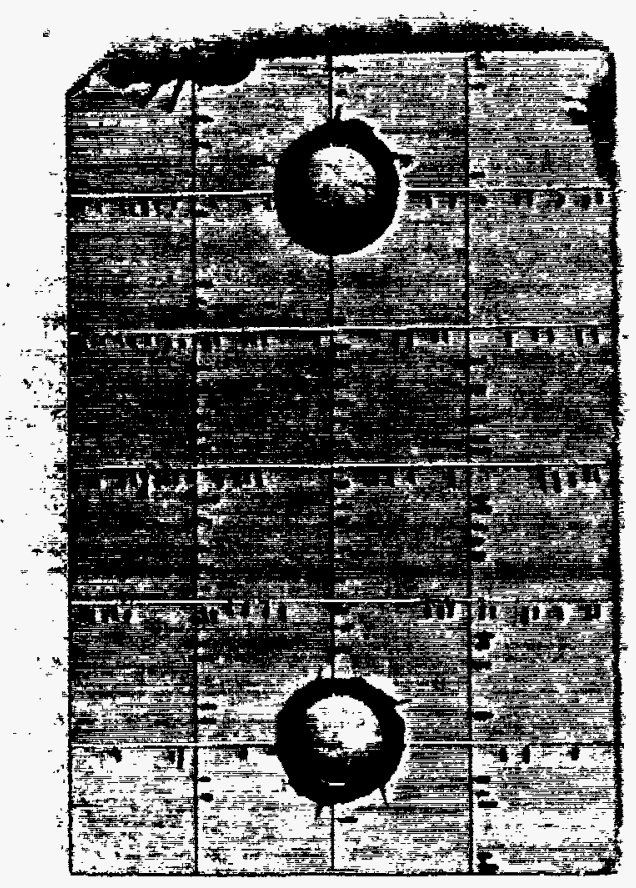

Figure 1. Paint-damaged Steel Specimen from Rag-filled Drum with Corrosion Sites Marked.

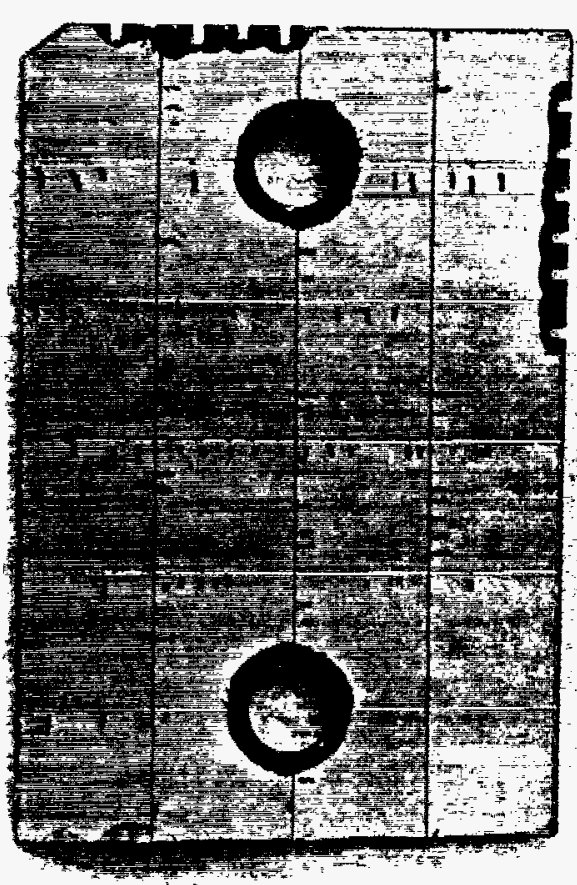

Figure 2. Paint-damaged Stee1 Specimen from Sand-filled Drum with Corrosion Sites Marked.

the atmosphere, a water film will tend to dissolve surface contaminants such as chlorides or sulfur compounds to destroy the protectiveness of the oxide. The importance of water films in the atmospheric corrosion of unprotected iron (Copson 1945) is the reason for continuous wetness monitoring as part of this test.

\subsection{CONCLUSIONS}

1. The extent of corrosion measured on bare low-carbon steel after a 1 -yr exposure in a metal shed was detectable but negligible for practical purposes.

2. Steel specimens with undamaged paint showed no visible corrosion, while those with damaged paint showed small sites where corrosion had begun to occur.

3. Steel protected by zinc showed no visible corrosion, whether the zinc was intact or had been removed to simulate damage. 


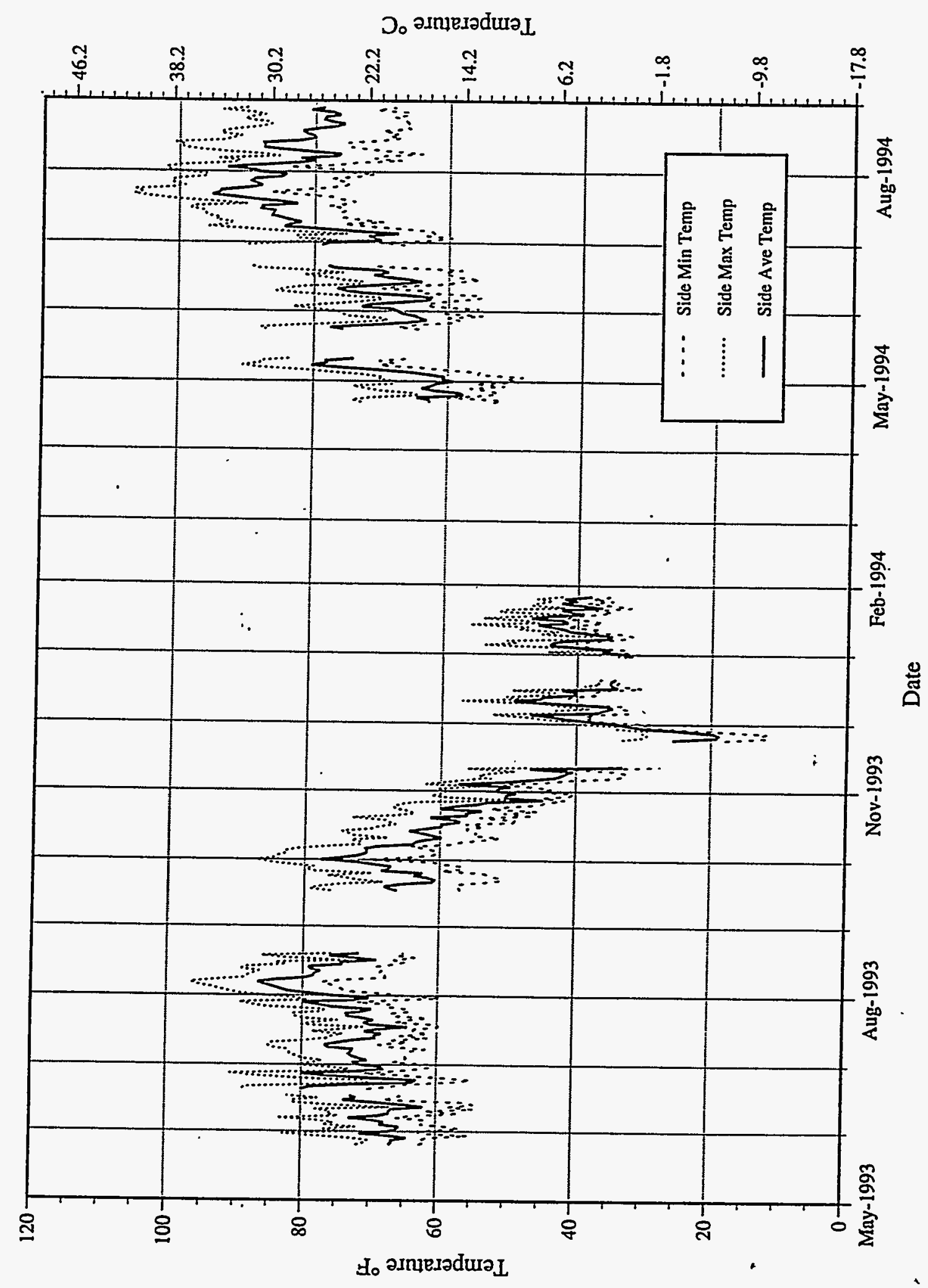

Figure 3. Temperature Measurements from Side of Rag-filled Drum for First 15 Months of Atmospheric Corrosion Test. 


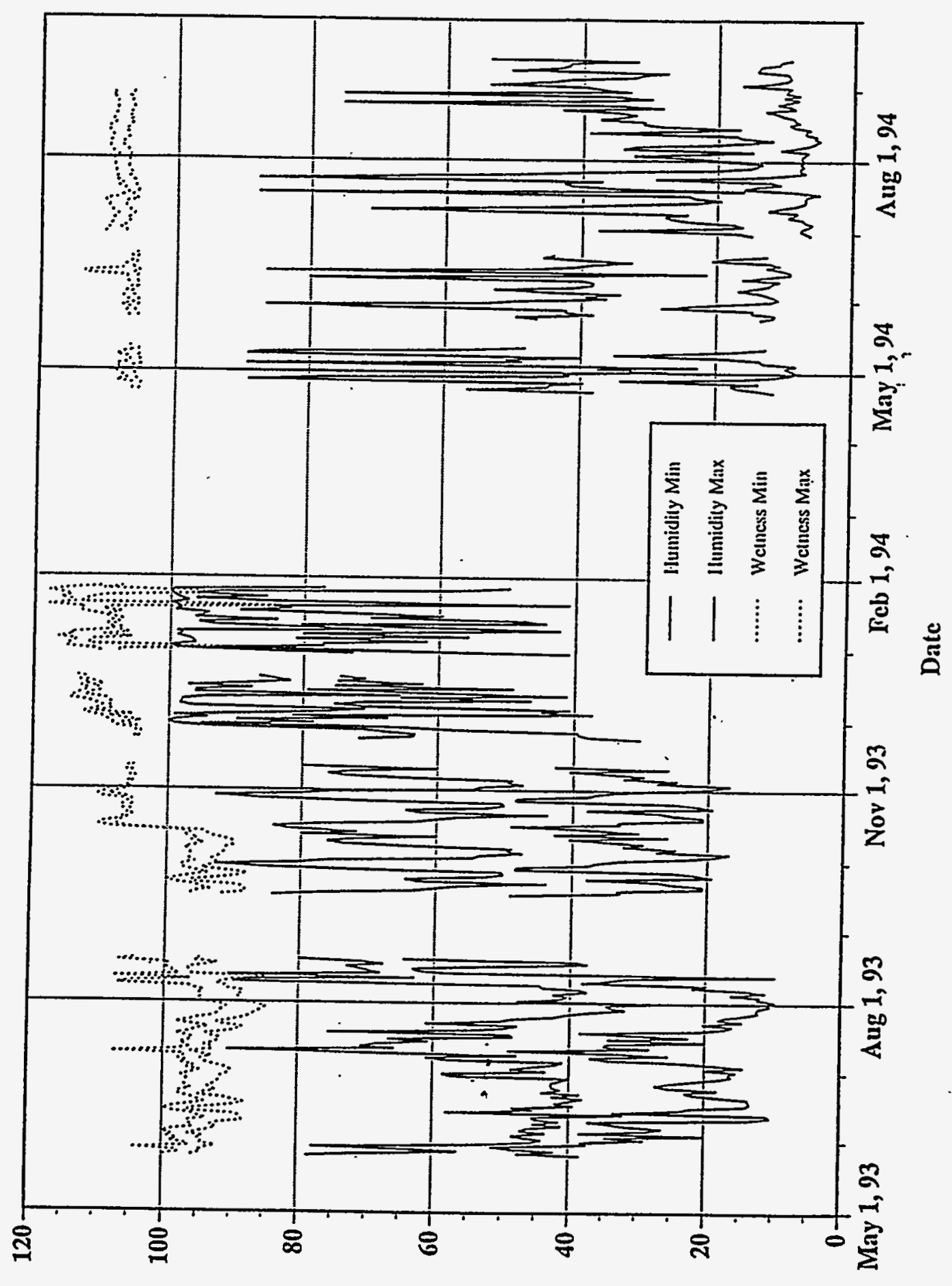

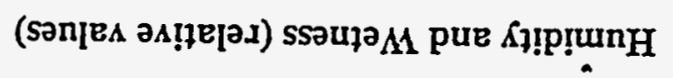

Figure 4. Humidity and Wetness Measurements for First 15 Months of Atmospheric Corrosion Test. 


\subsection{SOIL CORROSION}

\subsection{EXPERIMENTAL}

Specimens measuring $2.5-\mathrm{cm}$ by $6-\mathrm{cm}(1-\mathrm{in}$. by $4-\mathrm{in}$.) of bare carbon steel, painted steel, damaged painted steel, 304L steel, and galvanized steel were emplaced and later retrieved from soil at known depths to $9.1 \mathrm{~m}$ (30 ft). The specimens were attached with nylon screws to hexagonal polyethylene blocks to avoid galvanic corrosion. One specimen of each type at each of four depths, for six planned retrieval times for a total of 24 duplicate specimens were emplaced. Figure 5a shows a hexagonal block with specimens installed. To protect specimens from damage during retrieval drilling, these specimen blocks were inserted into $0.9-\mathrm{m}(3-\mathrm{ft})$ lengths of slotted polyvinyl chloride (PVC) casing (see Figure 5b). During specimen emplacement, soil removed from the intended burial depth was carefully packed around the hexagonal block inside the casing, and the assemblies were lowered into shafts drilled to the desired depths. Ground vibrations associated with extraction of drill casings are assumed to have packed the surrounding soil to a density approaching undisturbed soil. Six shafts were constructed to accommodate burial times of up to 16 years. Figure 6 out 1 ines the planned retrieval times, differing by factors of two, and the shaft layout. Instrumentation in a central shaft was described by Bunnell et a1. (1994). The last of these shafts was drilled during July 1994, when equipment was onsite for the 1-yr retrieval.

Specimens were retrieved by using a core-barrel drilling rig, in which a 36- to 46-cm- (14- to 18-in.-) diameter heavy-walled steel pipe was driven into the soil and then pulled to the surface with the soil column it contained. The pipe was oversized to the original shaft diameter of $30 \mathrm{~cm}$ (12 in.), and the shafts were originally drilled within $5 \mathrm{~cm}$ ( 2 in.) of plumb over their length. Thus, the retrieval technique was to simply redrill the original shaft at a slightly larger diameter to ensure the specimens would be captured.

\subsection{RESULTS AND DISCUSSION}

The nominal 6-mo retrieval was accomplished in March 1994, after an actual exposure time of 9 months. Specimens placed 1.5 and $3 \mathrm{~m} \mathrm{(5} \mathrm{and} 10 \mathrm{ft}$ ) below grade were retrieved easily. Those at the $6.1-\mathrm{m}(20-\mathrm{ft})$ level were more difficult to retrieve; one specimen was lost and others were damaged. The soil around the specimens at the 9.1-m (30-ft) level was very dry, which made it difficult to pull to the surface. Smaller-bore core barrels were tried, but the specimens and their plastic carrier were destroyed. Retrieval of the 1-yr specimens was accomplished in July 1994, but once again one of the specimen sets (buried 1.5-m deep) was destroyed during drilling. 


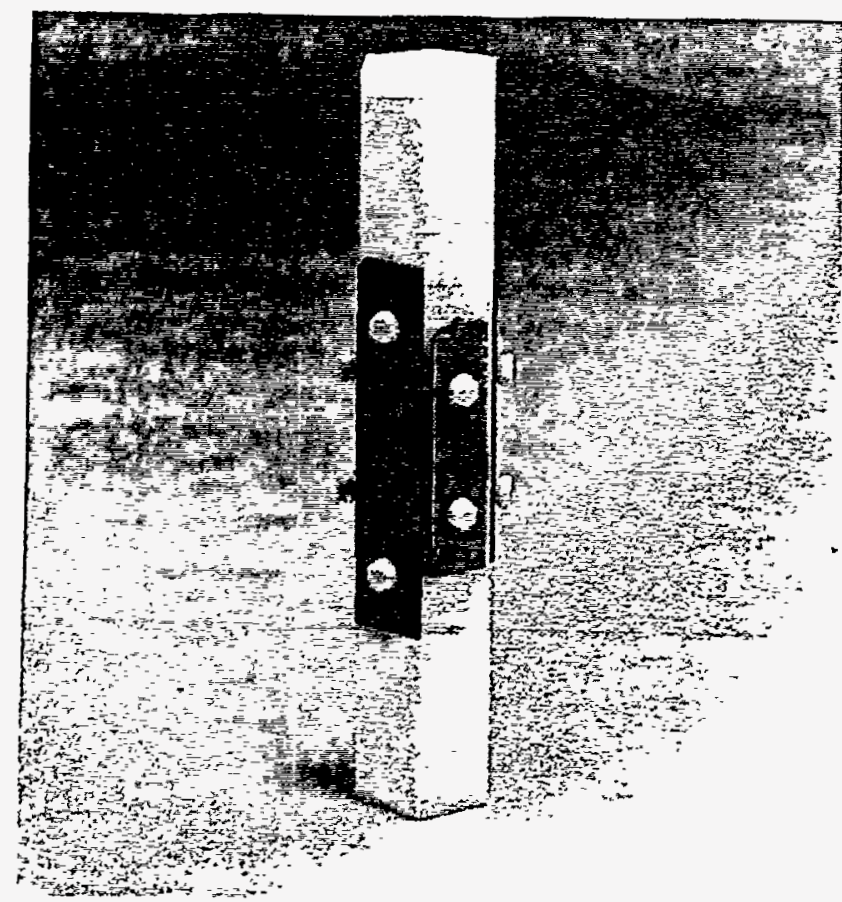

Figure 5a. Metal Specimens Attached to Polyethylene Block.

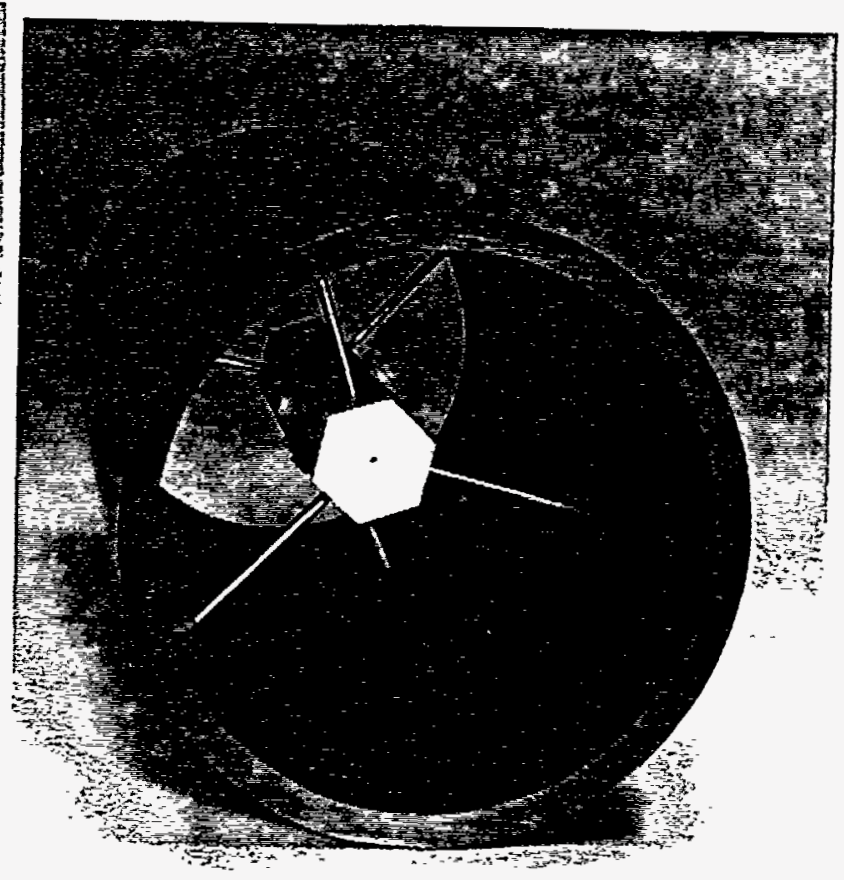

Figure 5b. Specimen Mounting Block in PVC in PVC Pipe, Ready for Burial.

After retrieval, specimens were photographed mounted on their polyethylene blocks, then removed and examined. Bare specimens of low-carbon steel and Type 304L stainless steel were cleaned of corrosion products by using CP-9 (see Section 2.1) for successively longer intervals, while observing for apparent complete corrosion product removal. Specimens were dried and then weighed to determine the amount of metal lost to corrosion.

Table 1 presents the 9-mo exposure results and Table 2 presents the 1-yr exposure results. Based on the 9-mo data, weight-loss measurements indicated that bare, low-carbon steel was corroded by contact with the soil at rates from 7.62 to $43.1 \mu / \mathrm{yr}(0.3$ to $1.7 \mathrm{mil} / \mathrm{yr})$. Weight- 1 oss measurements indicated that Type $304 \mathrm{~L}$ stainless steel was not corroded to a measurable extent in the 9-mo exposure. One-year data showed carbon steel corroding at rates between 5 and $25 \mu / \mathrm{yr}(0.19$ to $1.0 \mathrm{mil} / \mathrm{yr})$, and Type 304L stainless steel continued to corrode at a very low rate.

The low-carbon steel showed visible pitting after the first 9 months of exposure. The most obvious case was the bare specimen buried at the 3-m (10-ft) leve1. A digital micrometer was used to measure the depth of these pits. The metal thickness measured at pit sites was compared with the thickness of the specimen at sites where little or no corrosion had occurred. 

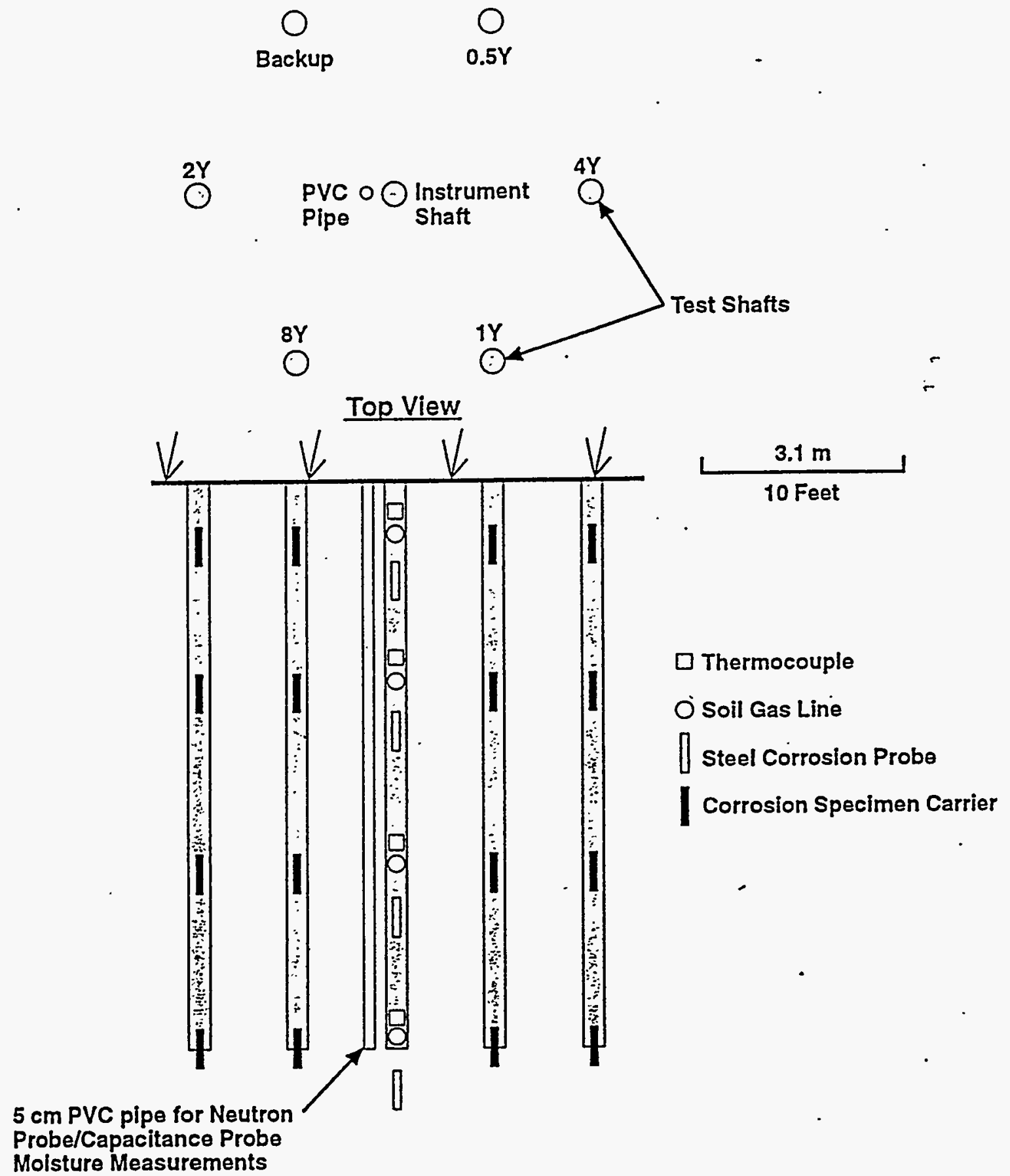

Side View

39409164.2

Figure 6. Shaft Layout at Soil Corrosion Site Showing Specimen and Instrument Locations. 
Table 1. General Corrosion Calculated from Weight-Loss Measurements (9-mo Exposure Duration).

\begin{tabular}{llll}
\hline Specimen Type & $\begin{array}{c}\text { Burial } \\
\text { Depth, } \\
\mathrm{m}(\mathrm{ft})\end{array}$ & \multicolumn{1}{c}{$\begin{array}{c}\text { Metal Loss, } \mu \\
(\mathrm{mi1})\end{array}$} & $\begin{array}{c}\text { Corrosion Rate, } \\
\mu / \mathrm{yr}(\mathrm{mi} / \mathrm{yr})\end{array}$ \\
\hline Low-C stee1 & $1.5(5)$ & $33(1.3)$ & $43.1(1.7)$ \\
304L SST & $1.5(5)$ & $0.1(4.9 \mathrm{E}-3)$ & $0.17(6.5 \mathrm{E}-3)$ \\
Low-C stee] & $3(10)$ & $17.8(0.7)$ & $22.86(0.9)$ \\
304L SST & $3(10)$ & $0.18(7.2 \mathrm{E}-3)$ & $0.24(9.6 \mathrm{E}-3)$ \\
Low-C stee1 & $6.1(20)$ & $5.08(0.2)$ & $7.62(0.3)$ \\
304L SST & $6.1(20)$ & Damaged - Unusable & \\
\hline
\end{tabular}

SST $=$ stainTess steel.

Table 2. General Corrosion Calculated from Weight-Loss Measurements (12-mo Exposure Duration).

\begin{tabular}{llll}
\hline Specimen Type & $\begin{array}{c}\text { Burial Depth, } \\
\mathrm{m}(\mathrm{ft})\end{array}$ & $\begin{array}{c}\text { Metal Loss, } \\
\mu(\mathrm{mi1})\end{array}$ & $\begin{array}{c}\text { Corrosion Rate, } \\
\mu / \mathrm{yr}(\mathrm{miT} / \mathrm{yr})\end{array}$ \\
\hline Low-C Stee1 & $3(10)$ & $25(1.0)$ & $25(1.0)$ \\
304L SST & $3(10)$ & $0.53(2.1 \mathrm{E}-2)$ & $0.53(2.1 \mathrm{E}-2)$ \\
Low-C Stee1 & $6.1(20)$ & $15(0.59)$ & $15(0.59)$ \\
304L SST & $6.1(20)$ & $0.5(1.8 \mathrm{E}-2)$ & $0.5(1.8 \mathrm{E}-2)$ \\
LOW-C SteeT & $9.1(30)$ & $4.8(0.19)$ & $4.8(0.19)$ \\
304L SST & $9.1(30)$ & $0.5(1.9 \mathrm{E}-2)$ & $0.5(1.9 \mathrm{E}-2)$ \\
\hline
\end{tabular}

SST = stainless steel.

Using five measurements, the average thickness of noncorroded metal was $0.1382 \mathrm{~cm}(0.0544$ in. $)$. The micrometer was sensitive to $\pm 2.5 \mu$ and the pit depth accuracy is similar in a pit of ideal shape, $i . e$. , the measuring tip must contact the bottom of the pit. The differences between this thickness and those measured at seven pit sites was $5.1,127,102,102,102,25$, and $127 \mu(0.0002,0.005,0.004,0.004,0.004,0.001$, and 0.005 in.). The maximum pitting rate is calculated at $178 \mu / \mathrm{yr}(0.007 \mathrm{in} / \mathrm{yr})$. The Type $304 \mathrm{~L}$ stainless steel specimen showed no visible indications of pitting at this exposure. 
Figure 7 shows corrosion rates of low-carbon steel as indicated by electrical resistance probes $\mathrm{placed}$ at various soil depths in a shaft located within $6.1 \mathrm{~m}(20 \mathrm{ft})$ of the shaft from which specimens were extracted. These measurements indicate that corrosion rates varied with depth and ranged from 25 to $76 \mu / \mathrm{yr}$ ( 1 to $3 \mathrm{mil} / \mathrm{yr}$ ). This is the same general range as that measured by weight-loss methods. However, the correlation at various depths was not good. For example, though the probe at $1.5 \mathrm{~m}(5 \mathrm{ft})$ below the surface is in good agreement with weight-loss measurements (corrosion rate of $35.6 \mu / \mathrm{yr}$ versus $43.2 \mu / \mathrm{yr}$ ), the agreement between the $3-\mathrm{m}(10-\mathrm{ft})$ probe $(78.7 \mu / \mathrm{yr})$ and the weight loss of the $3-\mathrm{m}$ specimen $(23 \mu / \mathrm{yr})$ is poor. Similarly, agreement between the $6.1-\mathrm{m}(20-\mathrm{ft})$ probe indicating a corrosion rate of $68.6 \mu / \mathrm{yr}$ is in poor agreement with the $7.6 \mu / \mathrm{yr}$ rate from weight-loss measurements. Figure 7 also includes data points (solid symbols) representing corrosion as determined from weight-loss measurements. The data measured by using electrical resistance probes all indicate a higher corrosion rate than obtained using weight-loss specimens.

During the spring of 1994, a capacitance probe was used to measure the moisture content of the soil at the test site, and the data obtained are plotted in Figure 8 . Comparing Figures 7 and 8 , the $10 \mathrm{w}$ corrosion rates at depths of 1.5 and $7.6 \mathrm{~m}$ below the surface do not correlate with the high moisture level at the $1.5-\mathrm{m}$ depth and the low value at the 7.6-m depth. Note that the soil moisture data do not suggest that the corrosion rates at the intermediate 3-m and 6.1-m depths would be comparatively high. Other factors beside soil moisture appear to be influencing the measured rates. For instance, the soil temperature near the surface varies much more during the year than at greater depth, and the result may be differences in soil chemistry. Further analysis of the data will be required to rationalize the observed corrosion rate differences.

Upon initial examination, some painted low-carbon steel specimens showed paint damage in smal1 areas, but 1ack of corrosion on the steel surfaces indicated that the damage occurred by mechanical means during retrieval. There were several other small areas showing corrosion sites, possibly indicating some damage despite care during installation. The epoxy paint used on the drum metal is strong but quite brittle and is subject to damage when contacted by hard objects such as rocks.

The damaged painted steel specimens showed very little corrosion in the exposed steel, and paint lifting had not occurred at the paint-steel interface. Corrosion was apparently too localized to spread laterally or lift paint. These characteristics are likety to be observed in specimens exposed for longer periods.

The galvanized specimens showed only slight and uniform dulling of the surface, indicating that zinc was lost to corrosion. The rate of zinc loss will be determined by metallographic methods. The determination will be made after more material is lost, using the specimens retrieved after a 2-yr exposure. 


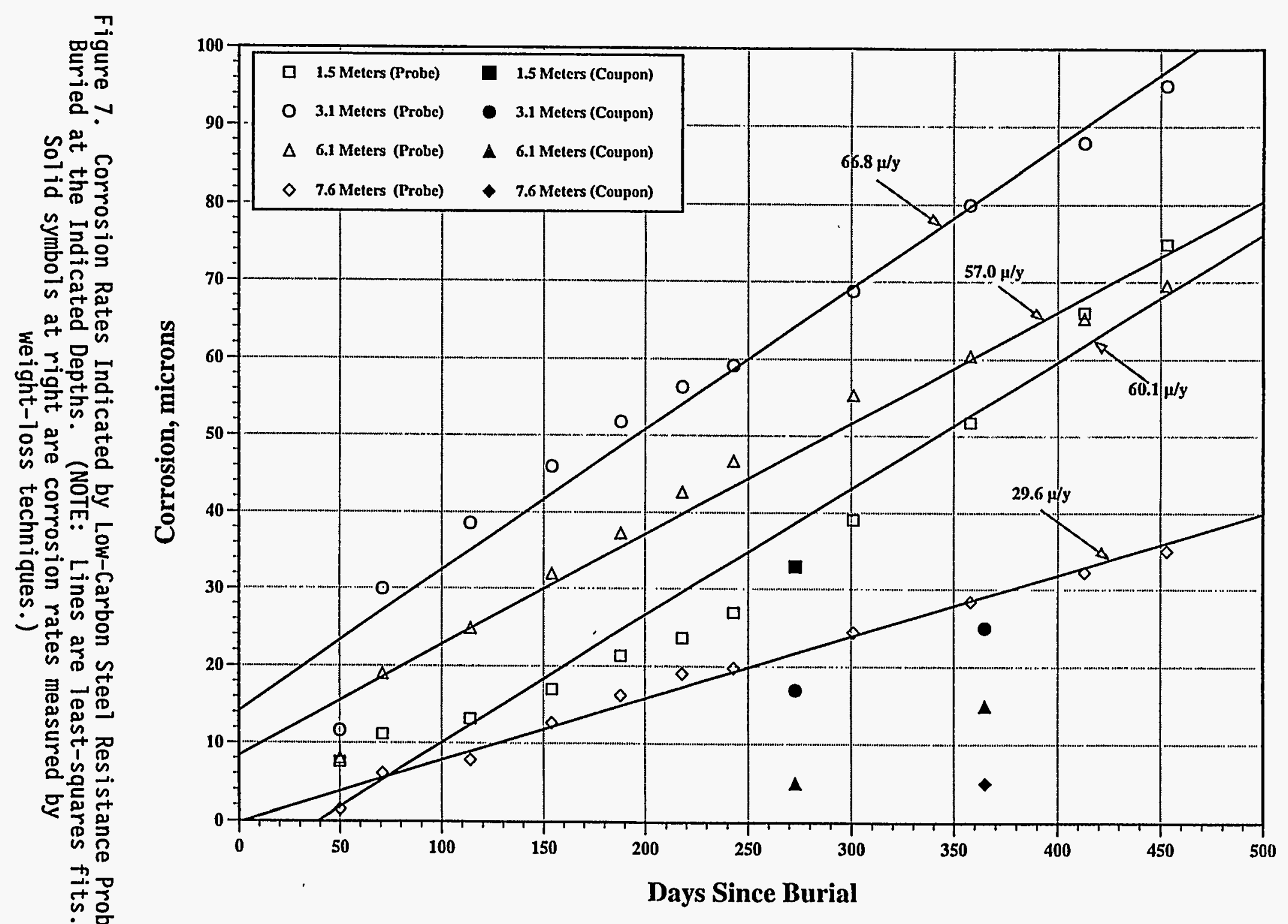

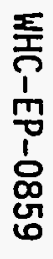


WHC-EP-0859

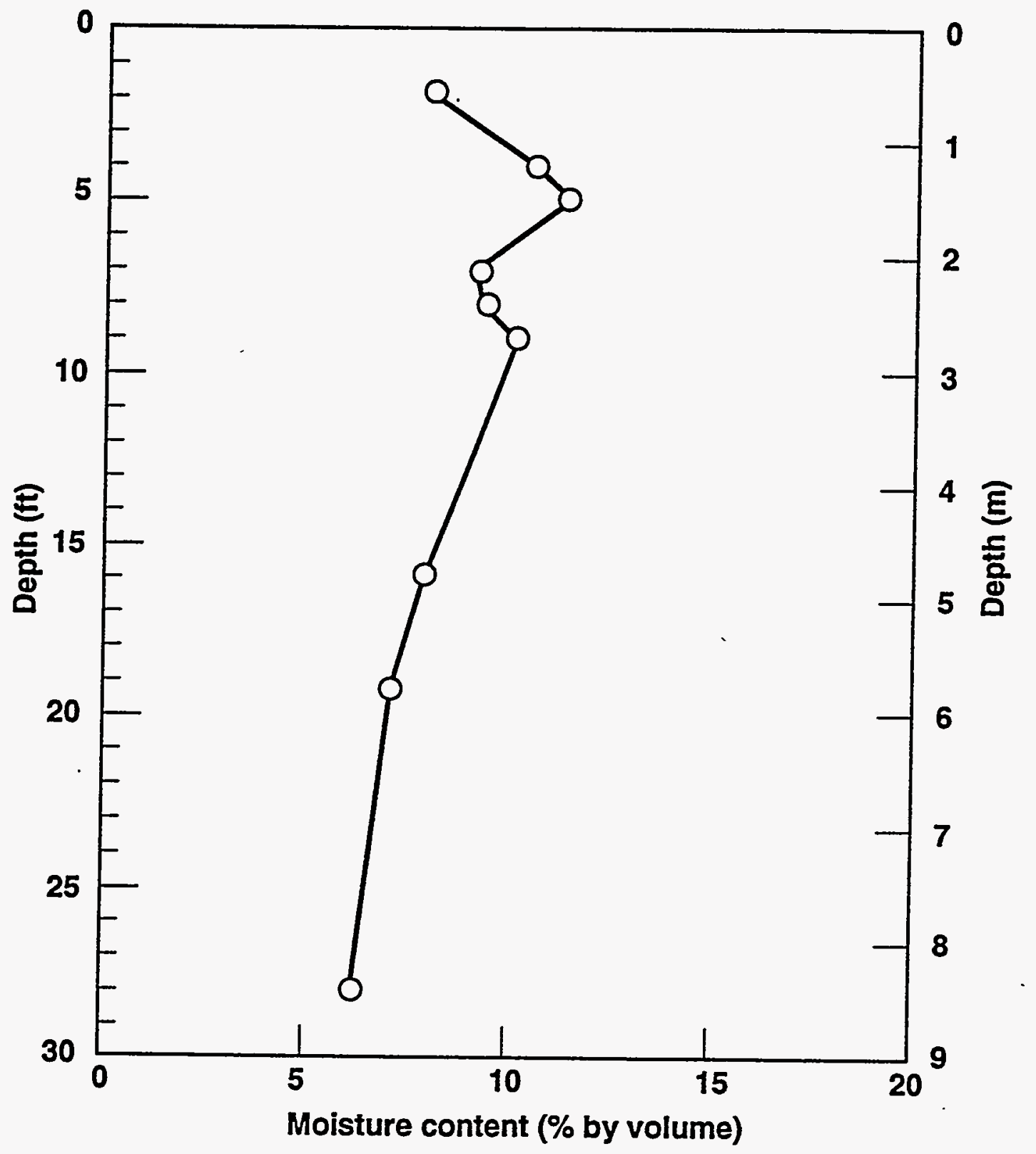

39411147.1

Figure 8. Soil Moisture Measurements at Soil Corrosion Site in Spring 1994 (made with capacitance probe). 
The Type 304L stainless steel specimens showed no visible corrosion and no pitting or other nonuniform corrosion. Height-loss measurements indicated negligible corrosion at this time of only 0.1 to $0.2 \mu$.

\subsection{CONCLUSIONS}

1. After 9 months of exposure to soil at the Hanford Site, bare lowcarbon steel appears, by both weight-loss measurements and electrical resistance probes, to be corroding at about 7.6 to $76 \mu / \mathrm{yr}$ ( 0.3 to $3 \mathrm{mil} / \mathrm{yr}$ ).

2. The measured maximum pitting rate in soil-exposed 10w-carbon steel is approximately $178 \mu / \mathrm{yr}(7 \mathrm{mil} / \mathrm{yr})$ after 9 months of exposure.

3. Type 304L stainless stee corrodes at a much lower rate than 70 carbon steel, 0.2 to $0.3 \mu / \mathrm{yr}(0.008$ to $0.011 \mathrm{mil} / \mathrm{yr})$ in Hanford soil and shows no pitting after 1 year of exposure. 


\subsection{SUMMARY}

Two tests are presently under way to measure the corrosion of painted low-carbon steel and possible alternative container materials. The tests focus on attacks by either the atmosphere or by soil at the Hanford Site. Alternative materials include galvanized steel and Type 304L stainless steel. Both of these tests include sensors to characterize the environment surrounding the exposed specimens.

The atmospheric corrosion specimens were retrieved after exposure for 6 and 12 months and the soil corrosion specimens after 9 and 12 months. These specimens were examined using standard methods, including visual observation and weight-7oss measurements. Atmospheric corrosion is visible on bare lowcarbon steel specimens, but associated weight losses indicate negligible corrosion to date. Soil corrosion is proceeding at a measurable and approximately constant rate on low-carbon steel. This rate is 7.6 to $76 \mu / \mathrm{yr}$ $(0.3$ to $3 \mathrm{mil} / \mathrm{yr})$, and the maximum pitting rate detected was approximately $180 \mu / \mathrm{yr}(7 \mathrm{mi} / \mathrm{yr})$. Type $304 \mathrm{~L}$ stainless steel corrodes at less than $1 \mu / \mathrm{yr}$ in the soil environment, based on the 12-mo measurements.

In general, corrosion has occurred at a very low rate in both cases, reflecting the relatively benign and dry environments at the Hanford Site. Future specimens are expected to show increasingly severity corrosion because of the longer exposure times. Those data will be analyzed and reported as available. 
WHC-EP-0859

\subsection{REFERENCES}

Copson, H. R., "A Theory of the Mechanism of Rusting of Low Alloy Steels in the Atmosphere," Proc. ASTH, 45, 544 (1945).

Bunne11, L. R., Doremus, L. A., Topping, J. B., Duncan, D. R., Task E Container Corrosion Studies: Annual Report, WHC-EP-0769, June 1994. 